\title{
Treatment of hepatitis $C$ in patients with thalassaemia. Where are we now?
}

\section{Geoffrey Dusheiko}

Royal Free Hospital, University College London, UK

\section{Oral presentation}

Oral presentation is available online

Correspondence: Geoffrey Dusheiko

CC Copyright G. Dusheiko, 2013

Licensee PAGEPress, Italy

Thalassemia Reports 2013; 3(s1):e25

doi:10.4081/thal.2013.s1.e25

This article is distributed under the terms of the Creative Commons Attribution Noncommercial License (by-nc 3.0) which permits any noncommercial use, distribution, and reproduction in any medium, provided the original author(s) and source are credited.

Parts of this work were presented at the

" 3 rd Pan-European Conference on Haemoglobinopathies and Rare Anaemias", Limassol (Cyprus), 24-26 October 2012. 